\title{
Impact of Covid-19 on Agriculture and Food Supply
}

\section{Shiamala Devi Ramaiya*}

Department of Crop Science, Faculty of Agriculture and Food Sciences, Universiti Putra Malaysia Bintulu Sarawak Campus, Bintulu, Sarawak, Malaysia

*Corresponding Author: Shiamala Devi Ramaiya, Department of Crop Science, Faculty of Agriculture and Food Sciences, Universiti Putra Malaysia Bintulu Sarawak Campus, Bintulu, Sarawak, Malaysia.

The Covid-19 continues to wreak havoc on many countries and create a lot of changes in people's everyday lives all over the world. As the Covid-19 pandemic is raging across the world, the broader economic crisis is also emerging and creating major challenges to food security and nutrition. Many of the affected countries have implemented a regional lockout policy. This strategy enforced a plethora of Covid-19 security measures such as movement control, supermarket, restaurant and market closure, quarantines and supply chain and trade disruption which greatly impacted agricultural production, food supply and demand.

About 820 million people worldwide suffer chronic hunger not eating enough caloric energy and balancing diet to lead healthy lives. They are extremely vulnerable to any interruption in their livelihood or to food access. Moreover, small-scale farmers are impervious as they hindered to working on their land and accessing markets to sell of their agricultural produces. For instance, evidence suggests that quarantines and panic during the outbreak of the Ebola Virus Disease (EVD) in Guinea, Liberia and Sierra Leone in 2014 - 2016 resulted in a spike in chronic food insecurity, hunger and malnutrition.

Protectionist measures across the globe could exacerbate the impact of the Covid-19. Panic-buying disrupts the distribution of food. As Covid-19 spreads, they temporarily produce many stockpiling staples and fresh produce, leaving markets empty. Agricultural economists worry about Covid-19 's current situation and impending implications. The food supply chain is a dynamic network involving producers, consumers, agricultural and fisheries input, processing and storage, transportation, and marketing. Disruptions are limited as food supply has been adequate for now, and markets have been stable. However, the limitation is prolonged, resulting in increased rates of food waste. This scenario is so apparent in rural areas, where the smallholders used to sell their produce on at morning and night markets. Small-scale farmers are vulnerable because they are prevented from working on their land and are likely to impede the access of farmers to markets, limit their productive capacity, and discourage them from selling their produce. Covid-19 is having a far greater impact than the end of the supply chain; farm workers, logistics suppliers and more are struggling to keep up and it affects the supply of fresh produce and staples. For example, lockdown and trade barriers across Asia due to the Covid-19 pandemic have pushed rice-one of the region's largest agricultural commodities firmly into the spotlight potential volatility in both supply and cost. This have raised fears over food supply. However, since 1st May the export quota of Vietnam have been removed and therefore the concerns over rice are now resolved.

Global eating patterns in the aftermath of the widening Covid-19 pandemic have changed drastically. Usually when lower incomes and uncertainty cause people to spend less and result in lower demand. Consumption habits and consumer behaviour shift globally and this scenario can be clearly observed among urban people because of restricted supply of fresh food. With stalls and restaurants closing down as entire countries get into lockdown; retailers across the world have been struggling to satisfy rising demand at the supermarket or via delivery apps. Canned foods and fast snacks are back in trend while some natural products are flying away from the shelves. During the lockdown, people are less visiting food markets that affect their food choice and consumption. Urban people more prefer to consume canned or processed foods and also fast foods. Survey that have even conducted at Italy shows that demand for ready to eat food that can be stored increased up to $60 \%$ for canned meat, $55 \%$ for canned beans and $22 \%$ for tomato sauce. These trends lead to difficulties to sell fresh produce. 
Maintaining a balanced diet during the Covid-19 pandemic is very critical according to FAO. No foods or dietary supplements can avoid infection with Covid-19, keeping a balanced diet is vital part of maintaining a good immune system. During these tough times it's still possible to buy and eat a balanced diet. Diets vary widely from place to place based on a lot of factors like eating habits and culture. However, when it comes to food, we know a lot about how to choose the right food combination to achieve a healthy diet regardless of where we live.

\section{Assets from publication with us}

- Prompt Acknowledgement after receiving the article

- Thorough Double blinded peer review

- Rapid Publication

- Issue of Publication Certificate

- High visibility of your Published work

Website: www.actascientific.com/

Submit Article: www.actascientific.com/submission.php

Email us: editor@actascientific.com

Contact us: +919182824667 